\title{
3,5,6-trichloro-2-pyridinyloxyacetic acid as effective thinning agent for fruit of 'Montenegrina' mandarin
}

\author{
Ácido 3,5,6-tricloro-2-piridiniloxiacético como raleante \\ químico efetivo de frutos da tangerineira 'Montenegrina'
}

\begin{abstract}
Mateus Pereira Gonzatto ${ }^{I}$ Gerson Nestor Böettcher ${ }^{I I}$ Leonardo André Schneider ${ }^{I I}$ Ângelo Azeredo LopesII Jairo Camargo Silveira Júnior ${ }^{I I}$ Henrique Belmonte Petry ${ }^{I I I}$ Roberto Pedroso de Oliveira ${ }^{\text {IV }}$ Sergio Francisco Schwarz ${ }^{\text {II }}$
\end{abstract}

\section{ABSTRACT}

The 'Montenegrina' mandarin (Citrus deliciosa Tenore) is widely cultivated in southern Brazil. This cultivar has a great tendency for alternate bearing, requiring thining of the fruit. However, the chemical thinners studied until now in this cultivar have not been successful. The objective of this research was to evaluate the effect of 3,5,6-trichloro-2-pyridinyloxyacetic acid (3,5,6-TPA) on the production and fruit quality of the 'Montenegrina' mandarin, in comparison with hand thinning and the options of chemical thinning previously studied. Hand thinning and no thinning were used as controls. Ethephon was applied in three doses: $200 \mathrm{mg} \mathrm{L}^{-1}$, 300mg $L^{-1}$ or 200mg $L^{-1}+3 \%$ urea; or 3,5,6-TPA, in four doses: 10, 20 , 30 or $40 \mathrm{mg} \mathrm{L}^{-1}$. Fruits of the hand thinned trees and those treated with $40 \mathrm{mg} \mathrm{L}^{-1}$ showed greater average size, greater distribution of commercial caliber and more orange colors. No treatment reduced alternate bearing. Applications of 40mg $\mathrm{L}^{-1}$ of 3,5,6-TPA as a chemical thinner, during the physiological drop of young fruit, had a similar effect that of hand thinning over yield and quality of fruits of 'Montenegrina'mandarin.

Key words: Citrus deliciosa Ten., 3,5,6-TPA, synthetic auxin ethephon, alternate bearing.

\section{RESUMO}

A tangerineira 'Montenegrina' (Citrus deliciosa Tenore) é amplamente cultivada no sul do Brasil. Possui grande tendência à alternância de produção, necessitando de raleio de frutos. Contudo, os raleantes químicos estudados até hoje nesta cultivar não se demonstraram eficientes. Este trabalho teve como objetivo avaliar o efeito do ácido 3,5,6-tricloro-2piridiniloxiacético $(3,5,6-T P A)$ sobre a produção e qualidade de frutos da tangerineira 'Montenegrina', em relação às opções de raleio químico previamente estudadas. Foram utilizados, como padrão, raleio manual e plantas sem raleio (controle). Realizaram-se aplicações de ethephon em três doses: $200 \mathrm{mg} L^{-1}$ $300 \mathrm{mg} \mathrm{L}^{-1}$ e 200mg $L^{-1}+3 \%$ de ureia; e aplicações de 3,5,6-TPA, em quatro doses: 10, 20, 30 e 40mg $L^{-1}$. Os frutos de árvores raleadas manualmente e de tratadas com 3,5,6-TPA a 40mg $L^{-1}$ apresentaram maior tamanho médio, melhor distribuição de calibres comerciais e cores mais alaranjadas. Nenhum tratamento reduziu a alternância de produção. Aplicações de 40mg $L^{-1}$ de 3,5,6-TPA como raleante químico, durante a queda fisiológica de frutos jovens, propiciaram efeito similar ao raleio manual sobre a produção e qualidade dos frutos de tangerineira 'Montenegrina'.

Palavras-chave: Citrus deliciosa Ten., 3,5,6-TPA, auxina sintética ethephon, alternância de produção.

\section{INTRODUCTION}

Cultivar 'Montenegrina' (Citrus deliciosa Tenore) is the main mandarin tree grown in southern Brazil, representing more than $30 \%$ of the planted area in the state of Rio Grande do Sul (JOÃO, 2010). This cultivar produces seeds, has a late maturation and a high tendency for alternate bearing, characterized by a year of bearing with high yield of small fruit and scarce flowering, followed by a year of insignificant fruit yield and abundant flowering (MARTÍNEZFUENTES et al., 2013). In order to obtain balanced

'Estação Experimental Agronômica, Faculdade de Agronomia, Universidade Federal do Rio Grande do Sul (UFRGS), 92990-000, Eldorado do Sul, RS, Brasil. E-mail: mpgonzatto@gmail.com. Corresponding author.

IIPrograma de Pós-graduação em Fitotecnia, Departamento de Horticultura e Silvicultura (DHS), Faculdade de Agronomia, Universidade Federal do Rio Grande do Sul (UFRGS), Porto Alegre, RS, Brasil.

IIIEstação Experimental de Urussanga, Empresa de Pesquisa Agropecuária e Extensão Rural de Santa Catarina (EPAGRI), Urussanga, SC, Brasil.

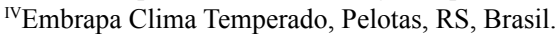


harvests with fruit diameter and quality suitable for commercialization, hand-thinning is a common practice (RODRIGUES et al., 1998). Nowadays, the recommendation for this cultivar is to combine pruning and hand-thinning of the fruit every year (SARTORI et al., 2007b).

Due to the large impact of handthinning on mandarin final production cost, various compounds were studied as chemical thinners for 'Montenegrina' mandarin trees. The best results in reducing the economic impact of labor were obtained using ethephon (2-chloroethylphosphonic acid, ET) in doses between 200 and $300 \mathrm{mg} \mathrm{L}^{-1}$, applied during the middle of physiological drop of young fruits (SOUZA et al., 1993). There are, however, several inconveniences, such as excessive thinning of fruit positioned on the external part of the canopy, leaf drop, phytotoxicity, and erratic behavior (SARTORI et al., 2007a, 2007b).

The

3,5,6-trichloro-2pyridinyloxyacetic acid (3,5,6-TPA) is a synthetic auxin that can increase fruit size in two main ways. When applied in the stage of cell division, it has a thinning effect on small fruit, decreasing the competition for carbohydrates amongst remaining fruits (AGUSTÍ et al. 1995). When applied in the early phase of cell growth, however, it increases the final size of the fruit, stimulating carbohydrate accumulation (AGUSTÍ et al., 2002). The thinning effect of this auxin is apparently due to a temporarily induced photosynthetic disorder, which leads to reduced production of photoassimilates and their absorption by young fruit, slowing down growth, and causing ethylene production and small fruit abscission. Following that, growth rates of the remaining fruit are increased, resulting in larger fruits (MESEJO et al., 2012). This auxin has been studied as a fruit thinner mainly in Satsuma (Citrus unshiu Marc.) and Clementine ( $\boldsymbol{C}$. clementina Hort. ex Tan.) mandarin (AGUSTÍ et al., 1995, 2002, 2007; MESEJO et al., 2012). There are also studies with the hybrid 'Fortune' mandarin ( $\boldsymbol{C}$. clementina Hort. ex Tan. $\times$ C. tangerina Tan.) (AZNAR et al., 1995), and the 'Murcott' tangor [C. reticulata Blanco $\times$ C. sinensis (L.) Osb.] (SERCILOTO et al., 2003). However, there are no studies with 'Montenegrina' mandarin trees or any other cultivar of the group of common mandarin trees (C. deliciosa Tenore).

This study aimed to evaluate the effect of various concentrations of 3,5,6-TPA applied during physiological drop of young fruit on the bearing, and fruit quality of the 'Montenegrina' tree, compared to hand-thinning and applications of ethephon, ET.

\section{MATERIALS AND METHODS}

The experiment was conducted in a commercial orchard $\left(29^{\circ} 37^{\prime} 24^{\prime \prime} \mathrm{S}, 51^{\circ} 25^{\prime} 54^{\prime \prime} \mathrm{W}\right)$ of 19-year-old 'Montenegrina' mandarin trees, in the city of Pareci Novo, Rio Grande do Sul State, Brazil. Orchard plants were spaced at $6.0 \mathrm{~m} \times 2.0 \mathrm{~m}$, grafted on trifoliate orange (Poncirus trifoliata Raf.), and the plants were pruned and hand-thinned annually. The soil is a Typic Ultisol, a sandy soil with $15 \%$ of clay. The climate of the region is classified as Cfa, subtropical humid with hot summers, according to Köppen (BERGAMASCHI et al., 2013).

The experiment consisted of nine treatments: Control; non-thinned trees; Handthinning, with manually fruit thinning on April $4^{\text {th }}, 2012$ (fruits with diameter of $36.5 \pm 0.8 \mathrm{~mm}$; effective thinning intensity of $66.2 \pm 6.5 \%$ ); 2-chloroethylphosphonic acid or ethephon applications (ET; Ethrel ${ }^{\circledR}$, Bayer Crop Science Ltda., São Paulo, Brazil), in three concentrations: $200 \mathrm{mg} \mathrm{L}^{-1}, 300 \mathrm{mg} \mathrm{L}^{-1}$ and $200 \mathrm{mg} \mathrm{L}^{-1}+3 \%$ of urea $(\mathrm{U})$; and 3,5,6-trichloro-2-pyridinyloxyacetic acid applications (3,5,6-TPA; MAXIM ${ }^{* \circledast}$, Dow Agro Sciences Ibérica S.A., Madrid, Spain) in four concentrations: 10, 20,30 and 40mg L $\mathrm{m}^{-1}$. Treatments with ethephon and 3,5,6-TPA were conducted during the middle of physiological drop of young fruit $(50 \%)$, which took place on November $12^{\text {th }}, 2011$, using foliar application with a motorized turbo spray with a spray volume of $2000 \mathrm{~L} \mathrm{ha}^{-1}$ with a pressure regulated nozzle at $200 \mathrm{lb} \mathrm{pol}^{-2}$.

Fruit abscission was evaluated 45 days after the middle of physiological drop of young fruits (DAPD), the moment the treatment was applied (November 12 $2^{\text {th }}, 2011$ ), being expressed regarding the existing fruit on branches during the initial drop (November $3^{\text {rd }}, 2011$ ). Two branches per plant were analyzed (east and west exposure), each presenting at least 100 fruit before the beginning of natural drop.

Fruit harvest was held on August $23^{\text {rd }}$, 2012. Fruit bearing was evaluated by counting the number of fruit (number tree ${ }^{-1}$ ) and measuring the total fruit mass produced $\left(\mathrm{kg} \mathrm{tree}^{-1}\right)$. Fruit load from flowering subsequent to chemical thinning was also evaluated, in March of 2013, based on the density of fruit per canopy area, according to 
RODRIGUES et al. (1998), in order to evaluate the alternate bearing.

Regarding fruit quality, 40 fruit were collected from each experimental unit and evaluated for fruit diameter and mass, by calculating the average diameter (d) and average fruit mass $\left(\mathrm{m}_{\mathrm{f}}\right)$. With this sample, the proportional distribution of fruit was estimated in four diameter classes: class $1(\mathrm{~d}>67 \mathrm{~mm})$, class $2(57-67 \mathrm{~mm})$, class $3(47-57 \mathrm{~mm})$ and unmarketable fruit $(\mathrm{d}<47 \mathrm{~mm})$. Color measurements were conducted in the fruit's equatorial region, with a Konica-Minolta ${ }^{\circledR}$ CR-400 colorimeter, using the color scale CIE1976 $L^{*} a^{*} b^{*}$. The following variables were determined from the calculation: chromaticity $\left[\mathrm{C}^{*}=\sqrt{\mathrm{a}^{* 2}+\mathrm{b}^{* 2}}\right]$ and color angle $\left[\mathrm{h}^{\circ}=\arctan \left(\mathrm{b}^{*} / \mathrm{a}^{*}\right)\right]$. When $\mathrm{C}^{*}$ assumes values near zero, greyish colors are represented, while values near 60 represent bright colors. Color angles $\left(\mathrm{h}^{\mathrm{o}}\right)$ close to $180^{\circ}$ represent greenish colors, close to $90^{\circ}$ yellowish colors and close to $0^{\circ}$, reddish colors (ORNELAS-PAZ et al., 2008).

The physicochemical properties of the juice were also analyzed, including juice content (JC), calculated by the ratio between the mass of the juice and of the fruit; soluble solids (SS) content, with direct reading in a digital refractometer with temperature compensation; titratable acidity (TA) by titration with $\mathrm{NaOH}$ $0.1 \mathrm{~mol} \mathrm{~L}^{-1}$ until $\mathrm{pH} 8.1$, expressed in percentage of citric acid; and maturation index (MI), calculated by the ratio SS/TA.

The experimental design used was completely randomized, with nine treatments and eight replicates, with one tree per experimental unit. A line of trees was kept as a margin between the experimental units, in order to avoid drifting. For the data analysis, we used the SAS 9.2 statistics package. The data for each response variable were first analyzed for normality and homogeneity of variance. Afterwards, results were submitted to parametric variance analysis (Fisher's test), the means being compared amongst each other using the Tukey's test $(\mathrm{P}<0.05)$.

\section{RESULTS AND DISCUSSION}

The fruit bearing in 2012 was affected by the thinning treatments. Trees that were not thinned (Control) presented higher fruit yield, while handthinned trees had the lowest performance. A high fruit load was obtained in all treatments, proving it was an 'on' year for the mandarin trees evaluated. All the chemical thinning treatments, with ethephon (ET) and 3,5,6-TPA obtained intermediate bearing (Table 1).
The fruit abscission, measured at 45 DAPD, was higher than $90 \%$ in all treatments. In trees that received applications of $40 \mathrm{mg} \mathrm{L}^{-1}$ of $3,5,6$-TPA and ET $200 \mathrm{mg} \mathrm{L}^{-1}+3 \%$ of urea (U), abscission rates of $98.6 \%$ and $97.9 \%$ were reached, respectively. The lowest abscission rates were $92.8 \%$ and $90.2 \%$, respectively, in hand-thinned and non-thinned trees (Table 1). More intense leaf drop and leaf renewals were observed only in trees that received ethephon.

None of the treatments were effective in the rupture of alternate bearing. In the posterior harvest, in March of 2013, an extremely low number of fruit was observed in the trees of all treatments $(<8$ fruits $\mathrm{m}^{-2}$ ), proving to be highly alternate trees in all treatments (RODRIGUES et al., 1998).

Plants that were treated with $40 \mathrm{mg} \mathrm{L}^{-1}$ of 3,5,6-TPA produced fruits larger in diameter $(\mathrm{d}=61.3 \mathrm{~mm})$ and in mass $\left(\mathrm{m}_{\mathrm{f}}=105.5 \mathrm{~g}\right)$. The smallest average sizes of the fruits were obtained with plants that were not thinned (Control) (Table 1). Regarding the commercial distribution of fruit by diameter, both hand-thinning and applications of 3,5,6-TPA at doses of 30 and $40 \mathrm{mg} \mathrm{L}^{-1}$ stood out: no non-commercial fruit sizes $(d<47 \mathrm{~mm})$ were reported. The best performances were obtained in trees treated with $40 \mathrm{mg} \mathrm{L}^{-1}$ of 3,5,6-TPA and the hand-thinned tress, in which more than $80 \%$ of the fruits were classified in classes 1 and $2(\mathrm{~d}>57 \mathrm{~mm})$. Fruits with $<47 \mathrm{~mm}$ were not reported in the 3,5,6-TPA treatment equal to or greater than $30 \mathrm{mg} \mathrm{L}^{-1}$ and in hand-thinning treatments (Figure 1).

The color angle $\left(\mathrm{h}^{\circ}\right)$ was affected by the treatments, both demonstrating more orange fruits in the trees sprayed with $40 \mathrm{mg} \mathrm{L}^{-1}$ of 3,5,6-TPA and handthinned trees, compared to the fruit of non-thinned trees. All other treatments did not differ in color when compared to the control. The fruit of all treatments displayed very bright colors $\left(C^{*}>60\right)$ (Table 2$)$.

Juice content (JC), titratable acidity (TA) and maturation index (MI) of fruits were not affected by thinning treatments. Only soluble solids content was higher in plants thinned with ET $200 \mathrm{mg} \mathrm{L}^{-1}+3 \%$ urea, in comparison to nonthinned plants (Table 2).

Application of $40 \mathrm{mg} \mathrm{L}^{-1}$ of 3,5,6-TPA reduced the number of fruit produced in comparison to control treatment and provided an increased abscission of young fruit, similar to the effect of ET at $200 \mathrm{mg} \mathrm{L}^{-1}$ with $3 \%$ urea (Table 1), which had the best performance in previous experiments (SOUZA et al., 1993). A similar effect was reported in a chemical thinning experiment with the 'Murcott' tangor with 3,5,6-TPA (15mg L-1), 
Table 1 - Fruit yield harvested in August 2012, fruitlet abscission, fruit diameter (d) and average fruit mass ( $\mathrm{m}_{\mathrm{f}}$ ) of 'Montenegrina' mandarin (Citrus deliciosa Tenore) subjected to different treatments of fruit thinning. Pareci Novo, RS, Brazil ${ }^{(1)}$.

\begin{tabular}{|c|c|c|c|c|c|}
\hline \multirow{2}{*}{ Treatments } & \multicolumn{2}{|c|}{-----------Fruit yield (2012)----------- } & \multirow{2}{*}{$\begin{array}{l}\text { Fruitlet }^{\text {abscission }}{ }^{(2)} \\
\qquad(\%)\end{array}$} & \multirow{2}{*}{$\begin{array}{c}\mathrm{d} \\
\left(\mathrm{mm} \text { fruit }^{-1}\right)\end{array}$} & \multirow{2}{*}{$\begin{array}{c}\mathrm{m}_{\mathrm{f}} \\
\left(\mathrm{g} \text { fruit }^{-1}\right)\end{array}$} \\
\hline & $\left(\mathrm{kg}\right.$ tree $\left.^{-1}\right)$ & (number tree ${ }^{-1}$ ) & & & \\
\hline Control & $67.7 \mathrm{a}$ & $1029.3 \mathrm{a}$ & $90.2 \mathrm{c}$ & $52.6 \mathrm{c}$ & $69.7 \mathrm{c}$ \\
\hline ET $300 \mathrm{mg} \mathrm{L}^{-1}$ & $47.4 \mathrm{ab}$ & $688.5 \mathrm{ab}$ & $95.8 \mathrm{ab}$ & $56.3 \mathrm{bc}$ & $82.3 \mathrm{bc}$ \\
\hline ET $200 \mathrm{mg} \mathrm{L}^{-1}+\mathrm{U} 3 \%$ & $38.6 \mathrm{~b}$ & $508.0 \mathrm{~b}$ & $97.9 \mathrm{a}$ & $57.7 \mathrm{ab}$ & $88.9 \mathrm{ab}$ \\
\hline ET $200 \mathrm{mg} \mathrm{L}^{-1}$ & $48.4 \mathrm{ab}$ & $619.5 b$ & $97.1 \mathrm{ab}$ & $55.7 \mathrm{bc}$ & $82.8 \mathrm{bc}$ \\
\hline 3.5.6-TPA $10 \mathrm{mg} \mathrm{L}^{-1}$ & $44.8 \mathrm{ab}$ & $558.5 b$ & $96.2 \mathrm{ab}$ & $56.8 \mathrm{abc}$ & $84.1 \mathrm{bc}$ \\
\hline 3.5.6-TPA $20 \mathrm{mg} \mathrm{L}^{-1}$ & $48.5 \mathrm{ab}$ & $641.5 b$ & $97.0 \mathrm{ab}$ & $57.9 \mathrm{ab}$ & $91.1 \mathrm{ab}$ \\
\hline 3.5.6-TPA $30 \mathrm{mg} \mathrm{L}^{-1}$ & $48.2 \mathrm{ab}$ & $592.3 b$ & $96.4 \mathrm{ab}$ & $58.9 \mathrm{ab}$ & $93.8 \mathrm{ab}$ \\
\hline 3.5.6-TPA 40mg L ${ }^{-1}$ & $46.1 \mathrm{ab}$ & $498.0 \mathrm{~b}$ & $98.6 \mathrm{a}$ & $61.3 \mathrm{a}$ & $105.5 \mathrm{a}$ \\
\hline Hand-thinning ${ }^{(3)}$ & $36.4 \mathrm{~b}$ & $416.5 b$ & $92.8 \mathrm{bc}$ & $59.8 \mathrm{ab}$ & $96.8 \mathrm{ab}$ \\
\hline$P$ & 0.0374 & 0.0009 & $<0.0001$ & $<0.0001$ & $<0.0001$ \\
\hline $\mathrm{CV}(\%)$ & 23.68 & 25.83 & 3.44 & 4.15 & 10.69 \\
\hline
\end{tabular}

${ }^{(1)}$ Means followed by different letters in columns are significantly different at the indicated $P$-value (Fisher's test) by Tukey's test $(P<0.05)$; ${ }^{(2)}$ Fruitlet abscission to 45 days after application of chemical thinners in the middle of physiological drop of young fruits $\left(\right.$ November $12^{\text {th }}$. 2011); ${ }^{(3)}$ Held on April $4^{\text {th }}, 2012$.

other auxins, and ethephon $\left(200 \mathrm{mg} \mathrm{L}^{-1}\right)$ (SERCILOTO et al., 2003). This fact demonstrates the efficiency of 3,5,6-TPA as a thinning agent on 'Montenegrina' fruit, resulting in bearing of fruit with larger diameter and mass, besides fruits with more intense coloring, similar to hand-thinning (Table 1).

The abscission of fruit in plants treated with chemical thinners, higher than $90 \%$, has also been reported in 'Marisol' mandarin

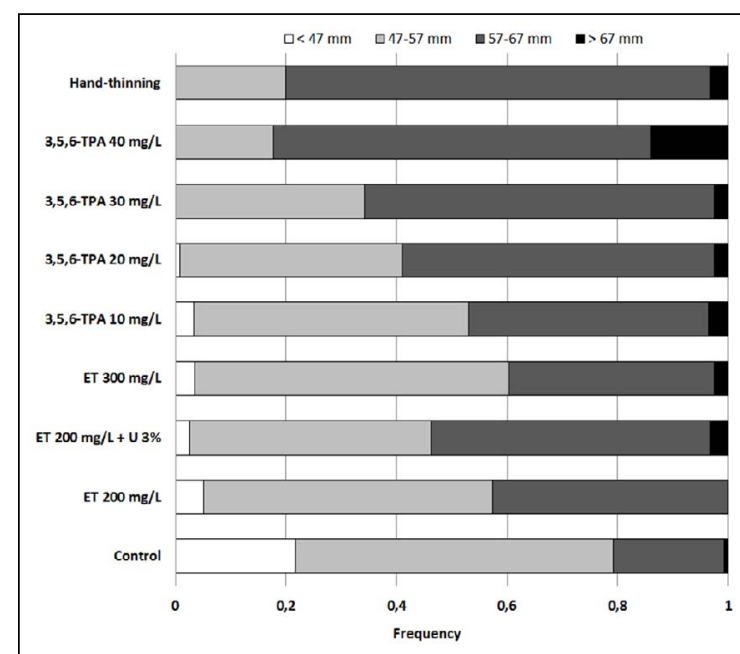

Figure 1 - Frequency distribution of commercial classes of frui diameter [class $1(\mathrm{~d}>67 \mathrm{~mm})$, class $2(57-67 \mathrm{~mm})$, class $3(47-57 \mathrm{~mm})$ and unmarketable fruits $(\mathrm{d}<47 \mathrm{~mm})]$, in function of different fruit thinning treatments on 'Montenegrina' mandarin (Citrus deliciosa Tenore) Fruits harvested in August 2012. Pareci Novo, RS, Brazil.
(C. clementina Hort. ex Tan.), 40 days after applying $15 \mathrm{mg} \mathrm{L}^{-1}$ of 3,5,6-TPA (MESEJO et al., 2012), applied in the same period of fruit development. However, in 'Clauselina' mandarin (C. unshiu Marc.) treated with $25 \mathrm{mg} \mathrm{L}^{-1}$ of 3,5,6TPA in subsequent period (cell elongation), the abscission rate was $67 \%$ (AGUSTÍ et al., 2007). In 'Murcott' tangor $[\boldsymbol{C}$. reticulata Blanco $\times \boldsymbol{C}$. sinensis (L.) Osb.], with 3,5,6-TPA applications after the drop of young fruit, the abscission rate was $42.5 \%$ (SERCILOTO et al., 2003), similar to ET applications at $200 \mathrm{mg} \mathrm{L}^{-1}$. However, the application of auxin (3,5,6-TPA) on effectiveness of chemical thinning on mandarins varies, when used in different concentrations or stages of fruit development (AGUSTÍ et al., 1995), with weather conditions, and between genotypes (cultivars).

The high fruit abscission rates obtained in this study were influenced by the chemical thinners application in early stages of fruit development (cell division), intensifying the physiological drop (GREENBERG et al., 2006). However, the high rates of abscission of the control and hand thinning treatments (90.2 to $92.8 \%$, respectively) are due to the low fruit load that occurred in the previous season (2011). The reduced fruit load induced low concentrations of endogenous gibberellins, favoring the signaling of floral induction (GRAVINA., 2007; MUÑOZFAMBUENA et al., 2012). This, combined with a large carbohydrate availability (RUIZ et al., 2001), resulted in an abundant bloom. This 
Table 2 - Juice content (JC), titratable acidity (TA), soluble solids (SS), maturation index (MI), hue angle $\left(\mathrm{h}^{\circ}\right)$ and chromaticity $\left(\mathrm{C}^{*}\right)$ of fruits of 'Montenegrina' mandarin (Citrus deliciosa Tenore) subjected to different treatments of fruit thinning. Pareci Novo, RS, Brazil $^{(1)}$.

\begin{tabular}{|c|c|c|c|c|c|c|}
\hline Treatments $^{(2)}$ & $\mathrm{JC}(\%)$ & TA (\%) & SS (\%) & MI & $\mathrm{h}^{\mathrm{o}}$ & $\mathrm{C}^{*}$ \\
\hline Control & 51 & 1.01 & $8.8 \mathrm{~b}$ & 8.9 & $85.8 \mathrm{a}$ & 61.8 \\
\hline ET $300 \mathrm{mg} \mathrm{L}^{-1}$ & 47 & 0.93 & $9.1 \mathrm{ab}$ & 9.9 & $83.4 \mathrm{ab}$ & 63.7 \\
\hline ET $200 \mathrm{mg} \mathrm{L}^{-1}+\mathrm{U} 3 \%$ & 52 & 1.07 & $10.3 \mathrm{a}$ & 9.8 & $84.1 \mathrm{ab}$ & 62.5 \\
\hline ET $200 \mathrm{mg} \mathrm{L}^{-1}$ & 51 & 0.99 & $10.2 \mathrm{ab}$ & 10.3 & $81.0 \mathrm{ab}$ & 63.4 \\
\hline 3.5.6-TPA $10 \mathrm{mg} \mathrm{L}^{-1}$ & 50 & 0.97 & $9.2 \mathrm{ab}$ & 9.5 & $82.5 \mathrm{ab}$ & 63.3 \\
\hline 3.5.6-TPA $20 \mathrm{mg} \mathrm{L}^{-1}$ & 52 & 1.03 & $9.6 \mathrm{ab}$ & 9.3 & $83.2 \mathrm{ab}$ & 62.2 \\
\hline 3.5.6-TPA $30 \mathrm{mg} \mathrm{L}^{-1}$ & 49 & 1.05 & $9.6 \mathrm{ab}$ & 9.2 & $80.2 \mathrm{ab}$ & 63.9 \\
\hline 3.5.6-TPA $40 \mathrm{mg} \mathrm{L}^{-1}$ & 48 & 1.03 & $10.2 \mathrm{ab}$ & 9.9 & $78.9 \mathrm{~b}$ & 63.9 \\
\hline Hand-thinning & 48 & 0.97 & $10.1 \mathrm{ab}$ & 10.4 & $78.7 \mathrm{~b}$ & 65.9 \\
\hline$P$ & 0.0631 & 0.0670 & 0.004 & 0.1405 & 0.0031 & 0.058 \\
\hline $\mathrm{CV}(\%)$ & 5.84 & 7.41 & 7.40 & 10.01 & 3.76 & 3.15 \\
\hline
\end{tabular}

${ }^{(1)}$ Means followed by different letters in columns are significantly different at the indicated $P$-value (Fisher's test) by Tukey's test $(P<0.05)$; ${ }^{(2)}$ Chemical thinners application (ET and 3,5,6-TPA) in the middle of physiological drop of young fruits (November 12 $\left.{ }^{\text {th }} .2011\right)$. Handthinning held on April $4^{\text {th }}, 2012$.

abundant flowering causes a high drop of young fruit, resulting in very low fruit set, which may reach values of 0.1 to $0.5 \%$ (SPIEGEL-ROY \& GOLDSCHMIDT, 1996). However, even with the high abscission occurred, a large fruit production was obtained in 2012 (Table 1).

The internal quality of the fruit was not greatly affected by treatments, similar to the 'Murcott' tangor (SERCILOTO et al., 2003) at concentrations of $15 \mathrm{mg} \mathrm{L}^{-1}$ of 3,5,6-TPA. The small effect the treatments had on the internal characteristics of the fruit is due to the fact that the application of growth regulators has an exclusive effect on the final size of the fruit, acting slightly on features of internal quality (SERCILOTO et al., 2003), which are determined during the third stage of fruit development. Nonetheless, all fruit remained above the minimum international standards for mandarin commercialization ( $\mathrm{CS} \geq 33 \%$; $\mathrm{IM} \geq 7.5)$ (OECD, 2010).

The best distribution of commercial sizes of fruit were observed in the treatments of $40 \mathrm{mg} \mathrm{L}^{-1}$ of 3,5,6-TPA, in comparison to the ET $200 \mathrm{mg} \mathrm{L}^{-1}$ $+\mathrm{U} 3 \%$ treatment. Although the abscission level between both treatments was similar, this may be linked to the phytotoxic action caused by the ET. Due to leaf drop caused by ET, a more effective flowering occurred and, therefore, reduced the availability of carbohydrates for longer periods of time for young fruit. This probably maintained smaller growth levels for a longer period of time, regarding the application of 3,5,6-TPA, which has a less prolonged action mechanism, restoring the growth rate of the fruit within a short period of time (MESEJO et al., 2012). This phenomenon appears to be linked to the time of application (physiological drop of young fruits), since in studies with application after this stage, in the early phase of cell elongation of the fruit, the distribution of fruit sizes was very similar between 3,5,6-TPA and ET (SERCILOTO et al., 2003).

Alternate bearing was not exceeded in the treatments studied, since the 19-year-old mandarin trees were already alternating for several years, despite the practice of hand-thinning and branch pruning. In this case of intense alternate bearing it is possible to enhance flowering after high bearing by foliar applications of urea (EL-OTMANI et al., 2004), paclobutrazol (MARTINEZ-FUENTES et al., 2013) and early fruit harvest (MUÑOZ-FAMBUENA et al., 2011). However, flowering excess can be reduced after low fruit yield through foliar sprays of gibberellic acid (40mg L-1) (GRAVINA, 2007). Gibberellic acid acts by $C i F T$ gene repression in leaves (MUÑOZ-FAMBUENA et al., 2012) during floral induction, which occurs, for 'Montenegrina' in southern Brazil, usually in July (RAMOSHURTADO et al., 2006).

\section{CONCLUSION}

In summary, 3,5,6-TPA acts as chemical fruit thinner on 'Montenegrina' mandarin when 
applied to physiological drop of young fruits. $40 \mathrm{mg}$ $\mathrm{L}^{-1}$ of 3,5,6-TPA application provides fruits with similar size to hand-thinning, however, superior to ethephon applications.

\section{ACKNOWLEDGEMENTS}

The authors would like to thank the Coordenação de Aperfeiçoamento de Pessoal de Nível Superior (CAPES) and Conselho Nacional de Desenvolvimento Científico e Tecnológico (CNPq) for financial support.

\section{REFERENCES}

AGUSTÍ, M. et al. Effect of 3,5,6-trichloro-2-pirydiloxyacetic acid on clementine early fruitlet development and on fruit size at maturity. Journal of Horticultural Science, v.70, p.955-962, 1995.

AGUSTÍ, M. et al. The synthetic auxin 3,5,6-TPA stimulates carbohydrate accumulation and growth in citrus fruit. Plant Growth Regulation, v.36, p.141-147, 2002.

AGUSTÍ, M. et al. Response of 'Clausellina' Satsuma mandarin to 3,5,6-trichloro-2-pirydiloxyacetic acid and fruitlet abscission. Plant Growth Regulation, v.53, p.129-135, 2007.

AZNAR, M. et al. Synthetic auxin phenothiol on fruit development of 'Fortune' mandarin. Journal of Horticultural Science, v.70, p.617-621, 1995

BERGAMASCHI, $\mathrm{H}$. et al. Boletins agrometeorológicos da estação experimental agronômica da UFRGS: série histórica 1970 - 2012. Porto Alegre, RS, 2013. Available from: <http:// www.ufrgs.br/agronomia/eea>. Accessed: Dec. 20, 2013.

EL-OTMANI, M. et al. Improved use of foliar urea on Clementine mandarin to manipulate cropping in a sustainable production system. Acta Horticulturae, v.632, p.167-175, 2004.

GRAVINA, A. Aplicación del ácido giberélico en Citrus: revisión de resultados experimentales en Uruguay. Agrociencia, v.11, n.1, p.57-66, 2007. Available from: <http://www.fagro.edu. uy/ agrociencia/VOL11/1/pag.\%2057-66.pdf>. Accessed: July $15,2013$.

GREENBERG, J. et al. Effects of auxins sprays on yield, fruit size, fruit splitting and the incidence of creasing of 'Nova' Mandarin. Acta Horticulturae, v.727, p.249-254, 2006.

JOÃO, P.L. A citricultura no Rio Grande do Sul. In: SOUZA, P.V.D. et al. (Coord.). Indicações técnicas para a citricultura do Rio Grande do Sul. Porto Alegre: FEPAGRO, 2010. p.15-16.

MARTÍNEZ-FUENTES, A. et al. Fruitload restricts the flowering promotion effect of paclobutrazol in alternate bearing Citrus spp. Scientia Horticulturae, v.151, p.122-127, 2013.

MESEJO, C. et al. Synthetic auxin 3,5,6-TPA provokes Citrus clementina (Hort. exTan) fruitlet abscission by reducing photosynthate availability. Journal of Plant Growth Regulation, v.31, p.186-194, 2012. Available from: <http://download. springer.com/static/pdf/704/art\%253A10.1007\%252Fs00344- 011-9230-z.pdf?auth66=1388945387_60b853b4b3c8c895ce0b1 983e3b354b9\&ext=.pdf>. Accessed: Jan. 3, 2014. doi: 10.1007/ s00344-011-9230-z.

MUÑOZ-FAMBUENA, N. et al. Fruit regulates seasonal expression of flowering genes in alternate-bearing 'Moncada' mandarin. Annals of Botany, v.108, p.511-519, 2011. Available from: $\quad<$ http://aob.oxfordjournals.org/content/108/3/511.full. pdf + html $>$. Accessed: Oct. 12, 2013. doi: 10.1093/aob/mcr164.

MUÑOZ-FAMBUENA, N. etal. Gibberellic acid reduces flowering intensity in sweet orange (Citrus sinensis L. Osbeck) by repressing CiFT gene expression. Journal of Plant Growth Regulation, v.31, p.529-536, 2012. Available from: <http://download. springer.com/static/pdf/338/art\%253A10.1007\%252Fs00344012-9263-y.pdf?auth66 $=1388945441$ ab338f845acf08fcbb1583 0d15cf4adf\&ext=.pdf $>$. Accessed: July 15, 2013. doi: 10.1007/ s00344-012-9263-y.

OECD (ORGANIZATION FOR ECONOMIC OPERATION AND DEVELOPMENT). International standards for fruit and vegetables: citrus fruits. Paris, 2010. 244p.

ORNELAS-PAZ, J.J. et al. Changes in external and internal color during postharvest ripening of 'Manila' and 'Ataulfo' mango fruit and relationship with carotenoid content determined by liquid chromatography-APcI+-time-of-flight mass spectrometry. Postharvest Biology and Technology, v. 50, p. $145-152,2008$.

RAMOS-HURTADO, A.M. et al. Diferenciação floral, alternância de produção e uso de ácido giberélico em tangerineira 'Montenegrina' (Citrus deliciosa Tenore). Revista Brasileira de Fruticultura, v.28, p.355-359, 2006. Available from: $<$ http:// www.scielo.br/pdf/rbf/v28n3/05.pdf>. Acessed: Jan. 3, 2014.

RODRIGUES, L.R. et al. Raleio manual de frutos em tangerineiras 'Montenegrina'. Pesquisa Agropecuária Brasileira, v.33, p.13151320, 1998.

RUIZ, R. et al. Carbohydrate availability in relation to fruitlet abscission in citrus. Annals of Botany, v.87, p.805-812, 2001.

SARTORI, I.A. et al. Raleio químico de tangerineira cv. Montenegrina (Citrus deliciosa Tenore) com pulverizações de etefon. Pesquisa Agropecuária Gaúcha, v.13, p.89-94, 2007 a.

SARTORI, I.A. et al. Efeito da poda, raleio de frutos e uso de fitorreguladores na produção de tangerineiras (Citrus deliciosa Tenore) cv. Montenegrina. Revista Brasileira de Fruticultura, v.29, p.5-10, 2007b.

SERCILOTO, C.M. et al. Desbaste e desenvolvimento do tangor 'Murcott' com o uso de biorreguladores. Laranja, v.24, n.1, p.95111,2003

SOUZA, P.V.D. de et al. Influência da concentração de etefon e pressões de pulverização foliar sobre a produção de frutos e o teor de substâncias de reserva em tangerineiras. Pesquisa Agropecuária Brasileira, v.28, p.613-619, 1993.

SPIEGEL-ROY， P.; GOLDSCHMIDT, E.E. Biology of horticultural crops: biology of citrus. Cambridge: Cambridge University, 1996. 230p. 